\title{
MRE11 Gene Mutation
}

National Cancer Institute

\section{Source}

National Cancer Institute. MRE11 Gene Mutation. NCI Thesaurus. Code C131805.

A change in the nucleotide sequence of the MRE11 gene. 